\title{
THE NATIONAL IMPORTANCE OF OUTDOOR SCHOOLS.
}

\author{
BY DR. FREDERICK ROSE, \\ M.A.
}

Few educational innovations of recent years have touched the popular imagination so quickly and so deeply as open-air or outdoor schools. Commenced a few years ago at Charlottenburg, the results obtained with comparatively simple equipment and common-sense treatment and teaching have been most remarkable. From Charlottenburg the movement spread to other parts of the German Empire. Then London took up the movement, and in some respects improved upon the original methods. London's example has been watched by the provinces, and Bradford, Halifax, Leeds, and other towns are following suit. The American teachers who visited England last year have taken back with them their impressions of London's outdoor schools, and this year Boston, Chicago, Milwaukee, and other great American cities are pushing forward the establishment of open-air schools.

The problem of the establishment of a large number of open-air schools in London is an extremely difficult one, because of the great lack of suitable spaces. Spaces in the great parks, commons, and open spaces cannot be enclosed and the necessary light structures erected, because the Parks Acts stand in the way. School playgrounds cannot be utilized, because they are quite unsuitable for the purpose, and are, moreover, needed by the other children. Outdoor schools cannot be established by the London authority outside the county boundary, according to the present interpretation of the Education Acts. The latter help the outdoor school movement so little that even the three present schools have to be run under the Epileptic (Education) Act of 1899 .

We are compelled, therefore, to fall back upon large private gardens, with adequate vegetation and quiet or rural surroundings, within the London area. Those to be had are very few in number, and then, most unfortunately, they do not as a rule lie in or near the congested areas where they are required, but in prosperous districts. Even when a suitable site is found, it is, compared with ordinary elementary schools, very expensive, because of the rent required and the temporary structural alterations and adaptations.

This question of expense is unfortunate, because it hinders the spread of outdoor schools. As a matter of fact, as far as buildings 
I82 THE BRITISH JOURNAL OF TUBERCULOSIS

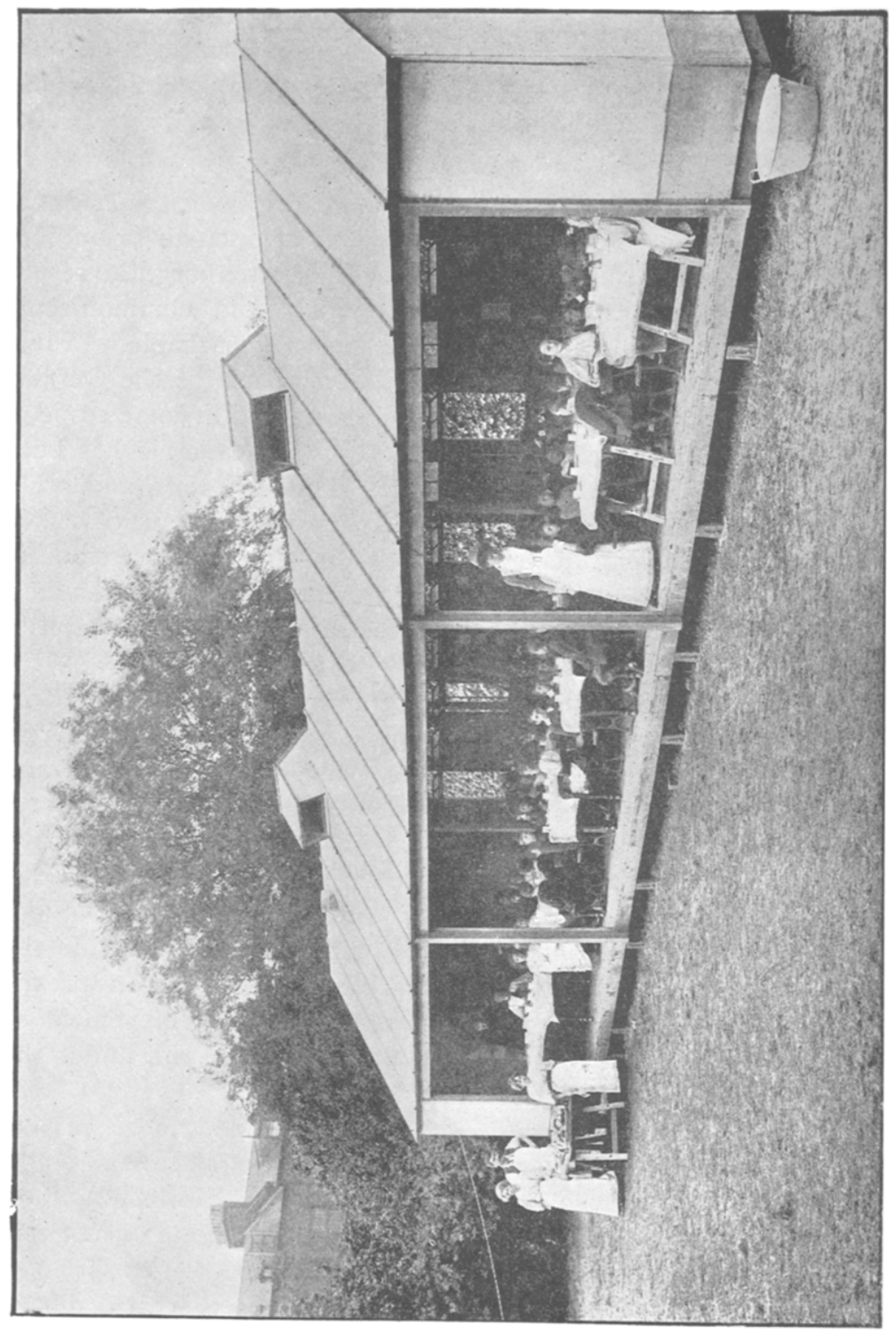

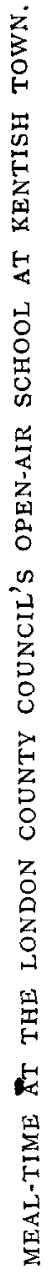


are concerned, outdoor schools should cost about two-fifths less than ordinary heavy school-buildings.

It seems clear that the question can be solved in one way onlythat is, the passing of a brief and non-contentious Education Actsay one or two clauses only-enabling London to establish open-air schools outside the county.

Such schools will not be day-schools, but residential schools. The advantages in favour of the latter type are many and indisputable. In the first place, the benefit to the children will be a double one. Six months' stay at a residential open-air school will be equal to a year at an open-air day-school, because the children will have the benefit of pure air, proper sleep, and quiet and clean surroundings during the whole of the twenty-four hours. In this way a residential open-air school, open the whole year, will treat double the number of children, as compared with the day open-air school. As far as maintenance is concerned, it is clear that as the children are fed in both types of schools, the further expenditure for simple sleeping accommodation need not be very great. As the schools can lie in the country forty or fifty miles from London, land can be bought in larger quantities, at greatly reduced prices, and with a wide variety in choice of sites. The buildings will be of fairly durable materials, of an artistic nature, and will be so constructed as not to cost more than $£ 20$ per place and to enable the children to be in the open air during practically five-sixths of the whole year, wholly by day, partially by night.

Let us now consider the part to be played by open-air schools in the prevention of tuberculosis, one of the classes of ailments with which they have to deal.

Tuberculosis in early life is probably less fatal than in adults. In attempting to procure reliable figures, we are faced by the old difficulty that investigators will not agree to work upon a uniform statistical basis. Sometimes they are based on mortality statisticsmostly from children in hospitals-sometimes on the results of clinical investigations. Whichever method is adopted, the results are alarming enough. In any case, we know definitely that children are very susceptible to tuberculous infection; that its presence is less evident, its results less fatal than in adults. But the most significant fact is that tuberculous disease remains more frequently in a latent form in children, and is, therefore, probably responsible for many sickly, illdeveloped, and backward children. If such children are forced into crowded, badly aired schoolrooms, and, in addition, burdened with school strain for six hours of the day during eight or nine years of their young lives, what must happen in many cases? Body-resistance is lowered, the latent disease gains the upper hand, and tuberculosis, in some form or other, develops. 
I84 THE BRITISH JOURNAL OF TUBERCULOSIS

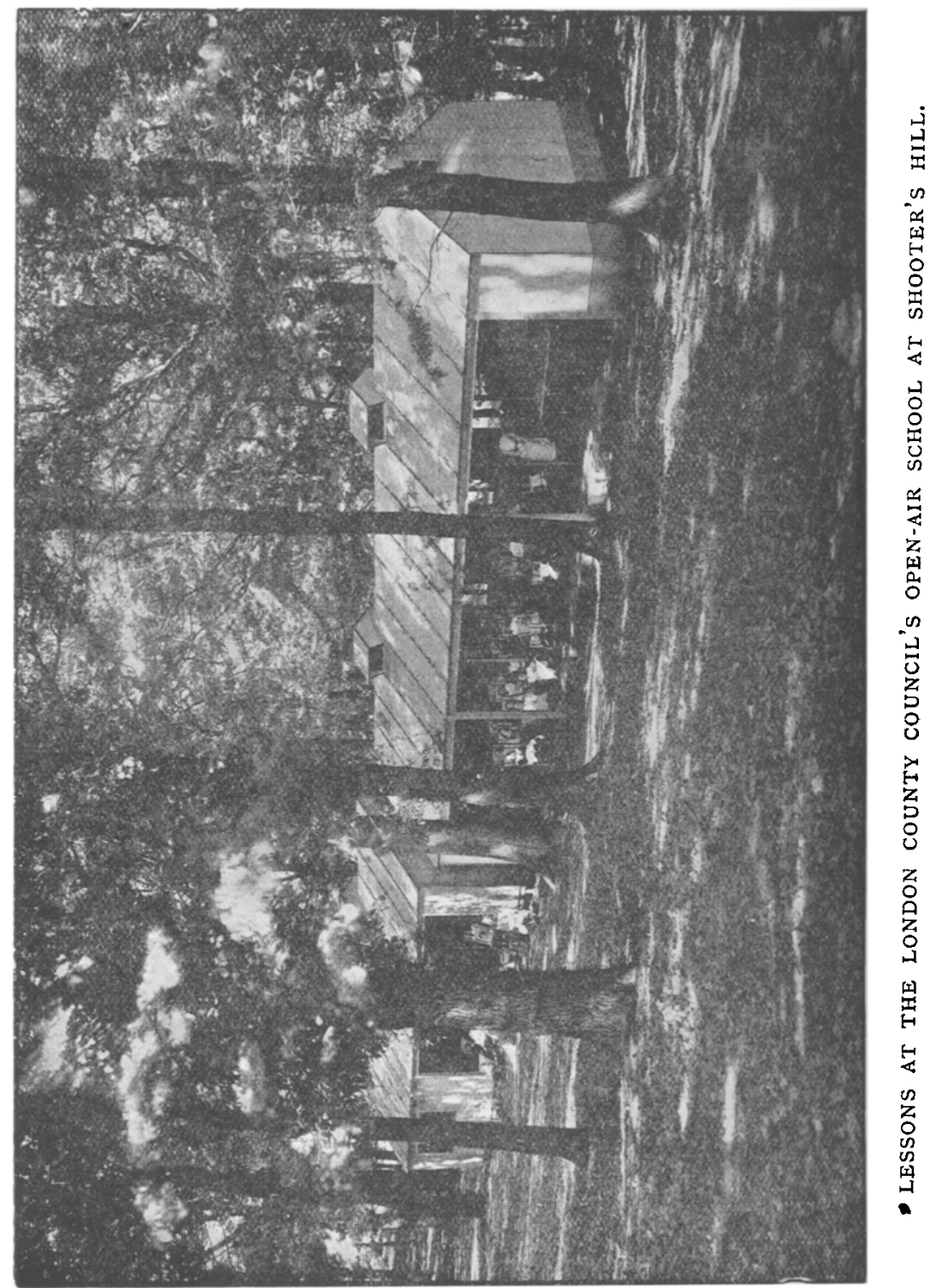


Now, quite briefly, what are the four great factors in the struggle against tuberculosis? Fresh air and suitable movement, scientific nutrition (including care of the teeth), proper sleep, and treatment when young. Nowhere can these factors be more fully or more universally utilized than in open-air schools, preferably those of a residential type.

The Boston committee put the matter briefly and accurately: "A child spends a large part of its life in a schoolroom. Strong and healthy children are those who have spent the most time in the open air. Life in the open air is the best investment one who is not strong can make. The nearer a schoolroom can approximate to the open air, the larger will be the return to the city on its investment in schools." I thank them for those words.

Open-air schools, of course, are not merely convalescent homes. To regard them as such would be a grave error. Their province is to teach and cure at the same time. The fact alone that in the future some 3 to 5 per cent. of all children in large towns may have to be treated in this manner forces us to consider carefully the educational side of the question, because large numbers of children cannot be withdrawn from the ordinary schools for long periods without their instruction being continued. The school-buildings of the future will be of a very different type, as a result of the experience gained in open-air schools. They will cost less, and the resultant saving will be devoted to the acquisition of larger spaces and every form of improved hygienic and educational apparatus. The curriculum, too, of the future school will be very different, as a result of the transference of the school-work from the closed class-room to the open air. It will be less literary, less abstract and unpractical, and will come into touch with actual observation and conditions and every possible form of outdoor activity.

It is curious to observe by what devious ways we are stumbling on the right methods of treatment of school-children. Take the feeding of school-children. This is by no means the mere feeding of necessitous children. It is the first step towards systematic buying, preparing, and serving of food on the most economical plan; towards the scientific body-building of the citizens of the future; towards the æesthetics of eating and the communal ideal of breaking bread with one's neighbour. At Bradford some six or seven persons, provided with the newest machinery, provide without undue efforts 4,000 scientifically prepared dinners daily. The careful study of methods of teaching mentally and physically defective children have taught us the secrets of brain development and its influence upon muscular activity, and paved the way for the education of normal children in the future. In a similar manner open-air schools, originally estab- 


\section{86 THE BRITISH JOURNAL OF TUBERCULOSIS}

lished for debilitated school-children, are pointing the way towards a reform in the whole system of elementary schools. It is by the condition of its elementary schools, not of its technical schools or Universities, that the future of the nation will be decided.

\section{OPEN-AIR SCHOOLS. \\ BIBLIOGRAPHY.}

Compiled by Dr. F. Rose.

\begin{tabular}{|c|c|c|c|c|}
\hline \multicolumn{3}{|c|}{ Author. } & \multicolumn{2}{|r|}{ Publisher. } \\
\hline $\begin{array}{l}\text { Dr. Neufert } \\
\text { Bendix. }\end{array}$ & and & Dr. & $\begin{array}{l}\text { "Die Charlottenburger Wald- } \\
\text { schule" (with six illustra- } \\
\text { tions). }\end{array}$ & $\begin{array}{l}\text { Urban und Schwarzenberg, } \\
\text { Berlin, N., Friedrich St., } \\
\text { I05B. }\end{array}$ \\
\hline Inspector Kö & & $\ldots$ & $\begin{array}{l}\text { "Die Waldschule in Mül- } \\
\text { hausen." }\end{array}$ & $\begin{array}{l}\text { Strassburger Druckerei und } \\
\text { Verlagsanstalt. }\end{array}$ \\
\hline Dr. Schaefer & & 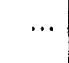 & $\begin{array}{l}\text { "Waldschule der Stadt Glad- } \\
\text { bach." }\end{array}$ & $\begin{array}{l}\text { Verlag Marrtin Hager, } \\
\text { Bonn. }\end{array}$ \\
\hline $\begin{array}{l}\text { Elberfelder V } \\
\text { Gemeinwoh }\end{array}$ & $\begin{array}{l}\text { Terein } \\
\text { ll. }\end{array}$ & für & $\begin{array}{l}\text { "Waldschule im Bergischen } \\
\text { Lande." }\end{array}$ & $\begin{array}{l}\text { Verein für Gemeinwohl, } \\
\text { Elberfeld. }\end{array}$ \\
\hline Dr. Bienstock & & $\ldots$ & $\begin{array}{l}\text { " Die Waldschule in Mül- } \\
\text { hausen." }\end{array}$ & $\begin{array}{l}\text { Strassburger Medizinische Zeit- } \\
\text { ung, I Heft, Igo7; Zeit- } \\
\text { schrift für Schulgesund- } \\
\text { heitspflege, No. II, Igo8; } \\
\text { Leopold Voss, Hamburg. }\end{array}$ \\
\hline W. Lange & & $\ldots$ & $\begin{array}{l}\text { " Die Charlottenburger Wald. } \\
\text { schule" (with four illustra- } \\
\text { tions). }\end{array}$ & Neue Bahnen, xviii., No. II. \\
\hline Dr. Bendix & & & $\begin{array}{l}\text { "Ueber die Charlottenburger } \\
\text { Waldschule" (with two } \\
\text { illustrations). }\end{array}$ & $\begin{array}{l}\text { Vierteljahrschrift für Gestund- } \\
\text { heitspflege. }\end{array}$ \\
\hline- & & & $\begin{array}{l}\text { "Verhandlagen der VIr. } \\
\text { Jahresversammlung des } \\
\text { Deutschen Vereins für } \\
\text { Schuldesundheitsplege." }\end{array}$ & $\begin{array}{l}\text { Verlag von Teubner, Ber- } \\
\text { lin. }\end{array}$ \\
\hline- & & & $\begin{array}{l}\text { Report of the London County } \\
\text { Council on the Open-Air } \\
\text { School at Bostall Woods, } \\
\text { No. r, I64 (with eight illus- } \\
\text { trations). }\end{array}$ & $\begin{array}{l}\text { King and Son, Great Smith } \\
\text { Street, Westminster. }\end{array}$ \\
\hline- & & & $\begin{array}{l}\text { Report of the London County } \\
\text { Council on the three Open- } \\
\text { Air Schools held during } \\
\text { Igo8 (with six illustrations). }\end{array}$ & $\begin{array}{l}\text { King and Son, Great Smith } \\
\text { Street, Westminster. }\end{array}$ \\
\hline Sir John Gors & & & $\begin{array}{l}\text { the "Children of } \\
\text { on." }\end{array}$ & Methuen. \\
\hline $\begin{array}{l}\text { Dr. Neufert } \\
\text { Rose. }\end{array}$ & and & Dr. & $\begin{array}{l}\text { Volume III. of Transactions } \\
\text { of the Second International } \\
\text { Congress of School Hygiene, } \\
\text { London. }\end{array}$ & $\begin{array}{l}\text { Royal Sanitary Institute, } \\
\text { Margaret Street, London, } \\
\text { W. }\end{array}$ \\
\hline Dr. Rose & $\ldots$ & $\ldots$ & "Open-Air Schools." & $\begin{array}{l}\text { Published by the Royal } \\
\text { Sanitary Institute, Mar- } \\
\text { garet Street, London, W. }\end{array}$ \\
\hline Dr. Rose & $\ldots$ & $\ldots$ & "Open-Air Schools." & $\begin{array}{l}\text { Progress, vol. iii., No. 2, } \\
\text { II, Southampton Row, } \\
\text { W.C. }\end{array}$ \\
\hline Dr. Rose & $\cdots$ &.. & "Open-Air Schools." & $\begin{array}{l}\text { Hall and Penny, Leman } \\
\text { Street, Whitechapel. }\end{array}$ \\
\hline
\end{tabular}




\section{OPEN-AIR SCHOOLS.}

BIBLIOGRAPIIY (continued).

\begin{tabular}{|c|c|c|}
\hline Author. & Title. & Publisher. \\
\hline Dr. Rose & "Open-Air Schools." & $\begin{array}{l}\text { Avchiv für Volkswohlfahrt, } \\
\text { Berlin, W., Nollendorf } \\
\text { Street, 29-3o. }\end{array}$ \\
\hline $\begin{array}{l}\text { Dr. Kraft } \ldots \\
\text { A. Holden Byles }\end{array}$ & $\begin{array}{l}\text { "Waldschulen." } \\
\text { "The Open-Air School" (with } \\
\text { twelve illustrations). }\end{array}$ & $\begin{array}{l}\text { Zürich, Verlag, Orell Füssli. } \\
\text { World's Work, January, } \\
\text { Igog 20, Bedford Street, } \\
\text { W C }\end{array}$ \\
\hline Halifax & $\begin{array}{c}\text { "Bremerside Open-Air } \\
\text { School." }\end{array}$ & $\begin{array}{c}\text { Halifax Education Com. } \\
\text { mittee. }\end{array}$ \\
\hline Bradford $\quad \ldots \quad \ldots$ & "Thackley Open-Air School." & $\begin{array}{l}\text { Bradford Education Com- } \\
\text { mittee. }\end{array}$ \\
\hline Board of Education ... & $\begin{array}{l}\text { "School Excursions and Va- } \\
\text { cation Schools." }\end{array}$ & Wyman and Sons. \\
\hline $\begin{array}{l}\text { Ernest Gray, L.C.C., } \\
\text { M.A. }\end{array}$ & "Open-Air Schools." & $\begin{array}{l}\text { North of England Educa- } \\
\text { tional Conference, Igog. }\end{array}$ \\
\hline $\begin{array}{l}\text { Boston (U.S.A.) School } \\
\text { Committee. }\end{array}$ & $\begin{array}{l}\text { School Document No. } 2 \text { : } \\
\text { "Tuberculosis amongst } \\
\text { School-Children, and the } \\
\text { Outdoor School." }\end{array}$ & $\begin{array}{l}\text { City of Boston (Mass.) } \\
\text { Printing Department. }\end{array}$ \\
\hline $\begin{array}{l}\text { Boston (U.S.A.) Asso- } \\
\text { ciation for Relief and } \\
\text { Control of Tuber- } \\
\text { culosis. }\end{array}$ & $\begin{array}{l}\text { Fifth Annual Report, con- } \\
\text { taining account of School } \\
\text { of Outdoor Life. }\end{array}$ & 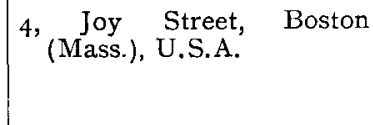 \\
\hline
\end{tabular}

Numerous references to the open-air school movement, together with illustrations of the outdoor schools of London, appear in "Tuberculosis in Infancy and Childhood." Edited by Dr. T. N. Kelynack. London: Baillière, Tindall and Cox. I908.

The above-mentioned German publications can be obtained through David Nutt, Long Acre, W.C.

Photographs and slides of the London County Council's Open-air Schools can be obtained on application to the Clerk of the Council. Slides of the German and American Open-air Schools can be procured from Chatham Pexton, 48, Gray's Inn Road, W.C.

[We are indebted to the courtesy of Messrs. Hasserodt and Co., 3I, Queen Street, London, E.C., for the loan of the blocks from which the accompanying illustrations have been prepared. These illustrations show the excellent type of Doecker buildings supplied by this firm. An illustration of "Resting Time at the London County Council's Open-Air School," at Horniman Park, Lordship Lane, appeared in this year's January number of $B . J . T$. An illustration of Dr. Frederick Rose's "Model of a Residential Open-Air School," appeared in the issue of B.J.T. for October, Ig08.--EDITOR, $B . J . T$.] 